\title{
Usefulness Analysis of Pre-War Consolidation Maps in Selected Procedures Determining Course of Borders on Example of Matyniów and Czarniecka Góra Units
}

\begin{abstract}
In the areas of the Russian partition, materials defining the course of the borders created during the interwar period are found. Such documents are prewar consolidations. Certified surveyors use similar materials in the work to determine the course of borders in fields. On the basis of the pre-war consolidations, they perform the activities of resuming the border marks in accordance with Art. 39 of the Geodetic and Cartographic Law or activities to establish the course of borders based on $\$ 39$ of the Regulation on the Land and Building Register.

In this article, land consolidation maps of the villages of Matyniów and Czarniecka Góra (located in the Konecki of Świętokrzyskie Voivodeship) were analyzed in order to check whether similar materials could form the basis for the resumption of the border marks.
\end{abstract}

Keywords: pre-war consolidations, resumption of border marks, land registry

Received: 29 March 2018; accepted: 20 June 2018

\footnotetext{
* AGH University of Science and Technology, Faculty of Mining Surveying and Environmental Engineering,Department of Engineering Surveying and Civil Engineering, Krakow, Poland

** The paper was prepared within the scope of the Dean Project of the faculty of Mining Surveying and Environmental Engineering (AGH University of Science and Technology)
} 


\section{Introduction}

In the areas of the Russian partition (where a classical cadastre did not exist) [1-3], materials defining the course of the borders created during the interwar period can be found [4]. Such documents include pre-war consolidations. These materials were created in the 30 s and 40 s of the $20^{\text {th }}$ century. These documents are still used by certified surveyors in activities whose aim is to determine borders in fields [5]. On the basis of the pre-war consolidations, surveyors perform the operations of resuming the border marks in accordance with Art. 39 of the Geodetic and Cartographic Law $[4,5]$ or activities to establish the course of the borders based on $\S 39$ of the Regulation on Land and Building Register [5].

According to Art. 39 of the Geodetic and Cartographic Law [6, 7], the activities of resuming border marks are subject to shifted, damaged, or destroyed marks whose locations have been previously determined (assuming there are documents based on which their original location can be reproduced). However, as emphasized in $[5,6,8]$, resuming the border marks can be performed when the data allows us to determine the position of themarks with the accuracy required by applicable law. When materials defining the locations of border marks do not meet the standards, it is necessary to carry out activities to establish the course of the borders in the mode of the Regulation on the Land and Building Register [9]. Currently, the required accuracy of determining the location of border points is $0.10 \mathrm{~m}$ in relation to the nearest points of the geodetic or measuring network [10] as the situational details of Group I of accuracy or $0.30 \mathrm{~m}$ in relation to the points of the Class I network [11].

In this work, land consolidation maps of the villages of Matyniów and Czarniecka Góra located in the Konecki of Świętokrzyskie Voivodeship were analyzed in order to check whether similar materials could form the basis for the resumption of the border marks.

\section{Subject of Study}

The subjects of the research were pre-war consolidation maps of the Matyniów and Czarniecka Góra cadastral units located in the Koneckie in the province of Świętokrzyskie Voivodeship (Fig. 1).

Manuscript maps and measurements on the ground were made in accordance with the technical manual for the performance of surveying work related to the reconstruction of the agricultural system in the following provinces: Białystok, Kielce, Lublin, Łódź, Nowogrodzki, Polesie, Warsaw, and Volhynia as well as in the administrative district of Vilnius [11].

The consolidation map of the Matyniów unit (fragment - Fig. 2) was prepared on the basis of a measurement carried out on the ground in 1933, and the measurement of land in Czarniecka Góra was made in 1932. 


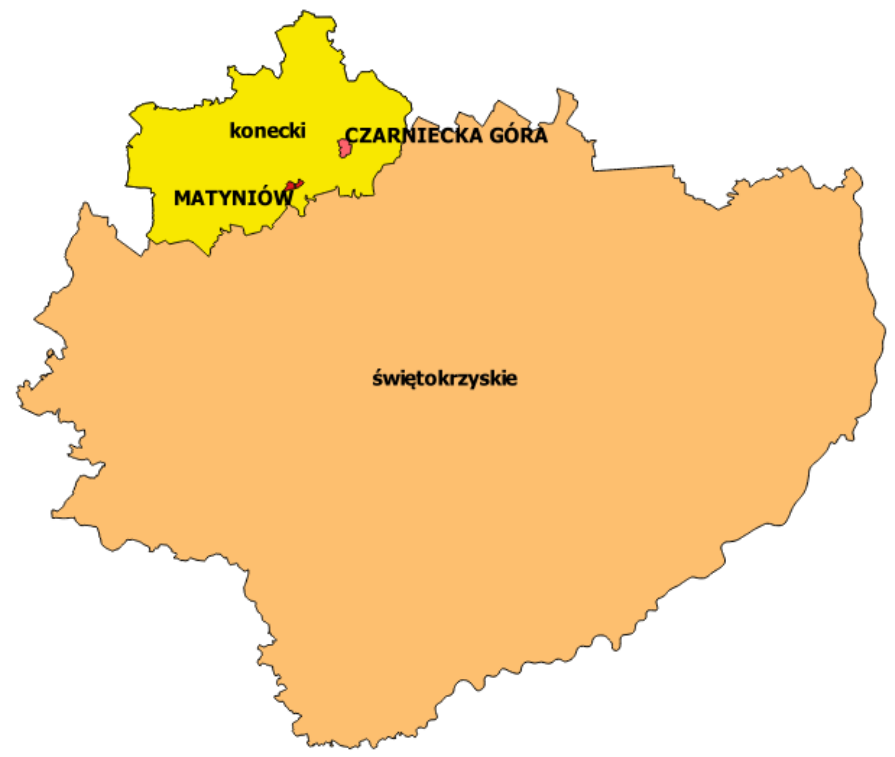

Fig. 1. Location of subject of study against background of Świętokrzyskie Voivodeship

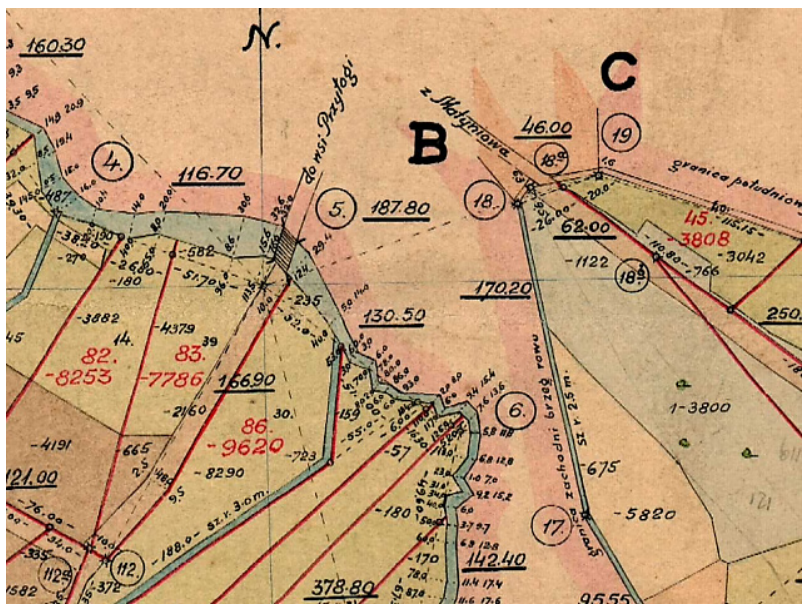

Fig. 2. Fragment of pre-war consolidation map of Matyniów area

Measurements of situational details in the 1930s were made on the basis of the construction matrix established for consolidation purposes. In the village of Matyniów, the measuring base was established in the form of a perimeter traverse covering the whole area of the consolidation and union sequences (Fig. 3). In the second analyzed example (due to the characteristics of the object), two perimeter sequences connected with union sequences were established (Fig. 4). 


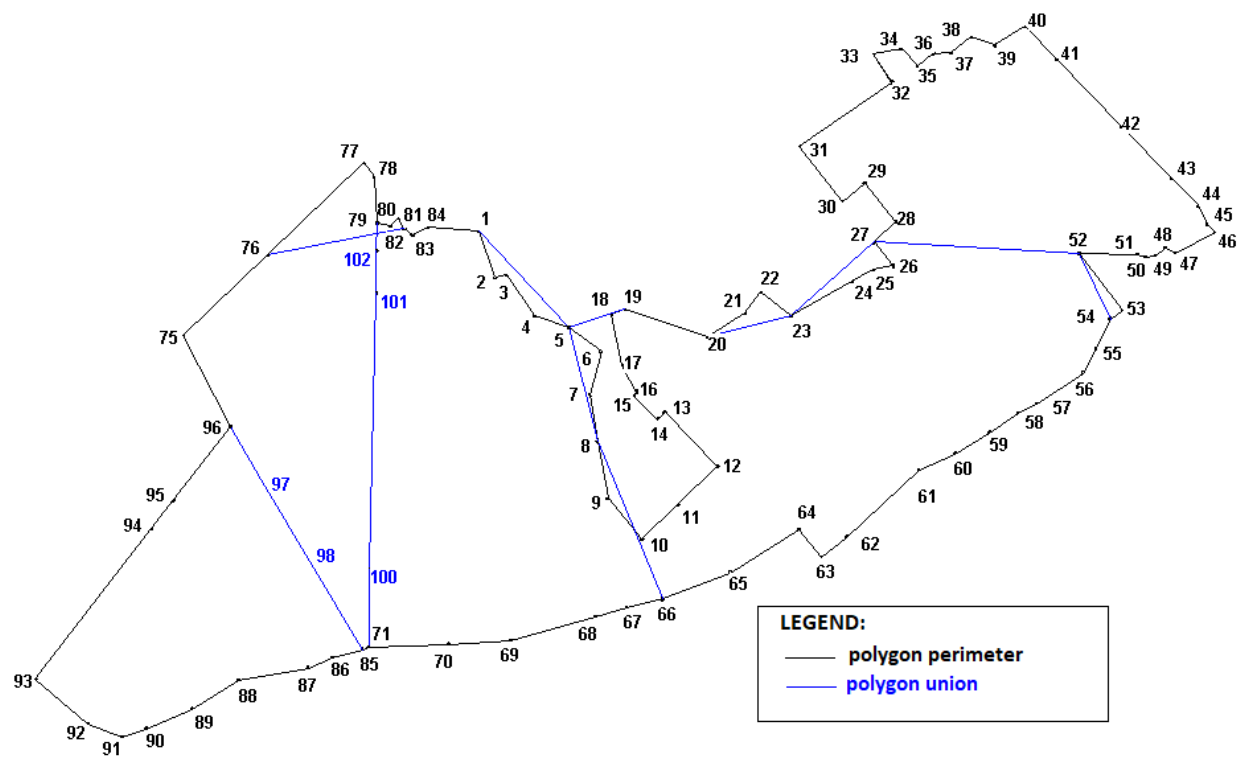

Fig. 3. Sketch of polygonal network established for purpose of merging village of Matyniów in 1933

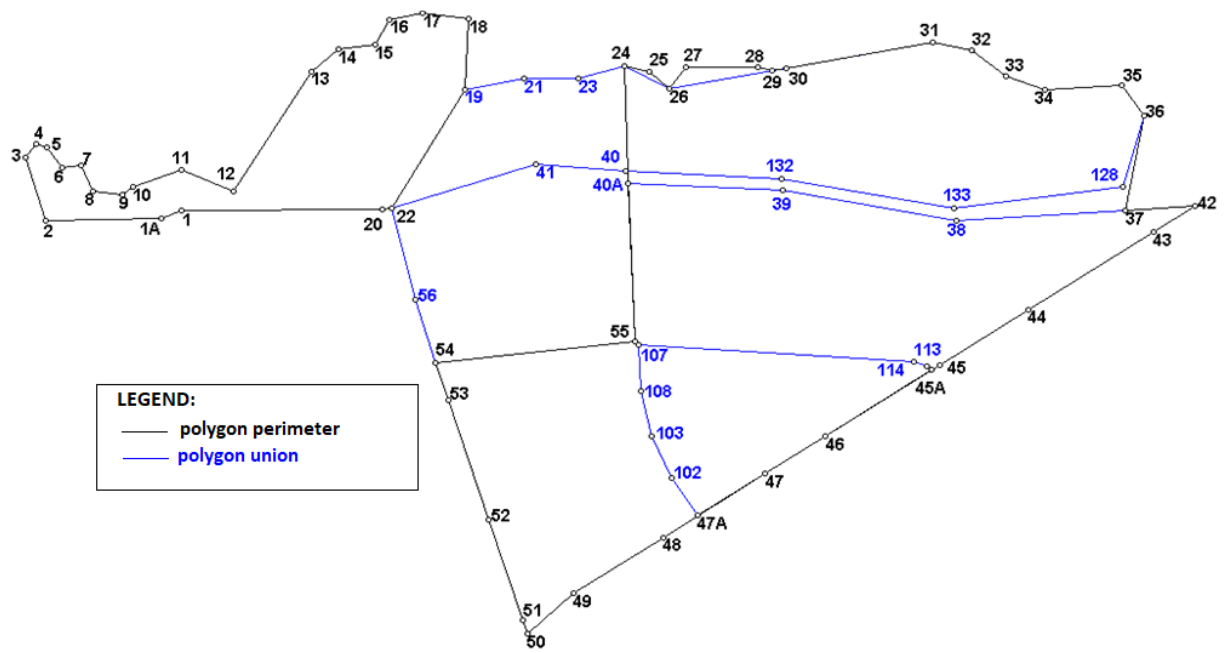

Fig. 4. Sketch of polygonal network established for purpose of merging village of Czarniecka Góra in 1932 
According to the technical instructions [11], measurements of the polygon sequences were carried out using classical methods. The angles were measured in two telescope positions with a one-minute theodolite. Side measurements were made twice with a 20-meter steel tape with an accuracy of $5 \mathrm{~cm}$. With large area denivelations (the sides of the polygon inclined to the level at an angle of more than $3^{\circ}$ ), the sides were reduced to a level. During the measurement, a measuring notebook was carried out on the ground, and field sketches documenting the course of the field work were prepared.

In both analyzed examples, the manuscript map of the consolidated land was made in 1933 according to the magnetic meridian. According to the technical instructions [11], the manuscript maps and plans could be plotted on scales: 1:5000, 1:4000, 1:2000, and 1:1000. The first map of the Matyniów unit was plotted on a scale of 1:4000, while the area of Czarniecka Góra on a scale of 1:2000. On the maps, a list of measures was prepared; i.e., a table of measured angles and the length of the assumed polygons of the control network. The list of measures is plotted on a separate table in which the bypass was initially described, followed by the individual union sequences.

The division project was drawn up and crossed out on the manuscript map. When designing, the principle was applied from the general to the specific. For this purpose, the main roads were initially designed, followed by complexes (parcel groups) and individual parcels. The designed plots were leveled in the complexes. The project was prepared in such a way that the area subject to division was divided into closed polygons in which the boundaries of individual plots could be designated on the ground only by means of tape [11].

A measurement survey was created from the whole work, which had to be performed chronologically in the order of the technical work. The survey consisted of a manuscript map, a final plan of consolidation, two copies of the measuring registers, a measuring notebook and field sketches, surface calculations and coordinates of individual border points, boundary reports, returning copies of the parties' invocations, sketches, and descriptions of stabilized underground signs [11]. For the objects analyzed from the measurement survey, only the manuscript maps and consolidation plans have been preserved in PZGiK (pol. Państwowy Zasób Geodezyjny i Kartograficzny - Geodetic and Cartographic State Resource). However, the other documents did not survive.

The merged maps were colored; the colors distinguished the method of land development. Arable land is marked in yellow, habitats - brown, meadows - green, forests - orange, roads - brown, and ditches and water - blue.

In accordance with the act of 1923 on land consolidation [12], the consolidation project was approved by the regional land office. From 1932, the voivode became the head of the district office [13]. The analyzed consolidations were approved by a decision issued by the voivode of Kielce. 


\section{Field Work}

According to the technical instructions from 1925 [11], the basis for measuring the land included in the consolidation was a polygonal network consisting of the perimeter polygon and union polygon trains (Figs. 3, 4). Measurements of the boundary marks and other situational details were made from polygon points using the orthogonal method with the use of tape [14].

In accordance with the instructions [11], the points of the polygon trains were stabilized in the form of heavily hardened border mounds in the form of a truncated cone with a diameter of $2 \mathrm{~m}$ and height of $0.5 \mathrm{~m}$. A wooden stake was driven inside the mound. On swampy lands or built-up areas, piles of wood were stuck, or other border marks were used in the form of concrete or stone posts; then, no boundary mounds were formed.

\subsection{Matyniów Unit}

As a part of this analysis, field work was carried out during which 15 out of 94 network points used for the consolidation of land in Matyniów were found and identified. During the measurement in built-up areas, the same stabilization of the polygon points in the form colloquially called "ocios" by the surveyors (i.e., handmade border marks made of sand stones) was observed (Fig. 5). On some signs up to today (after more than 80 years), hand-made centers in the form of crosses have been preserved (Fig. 6).

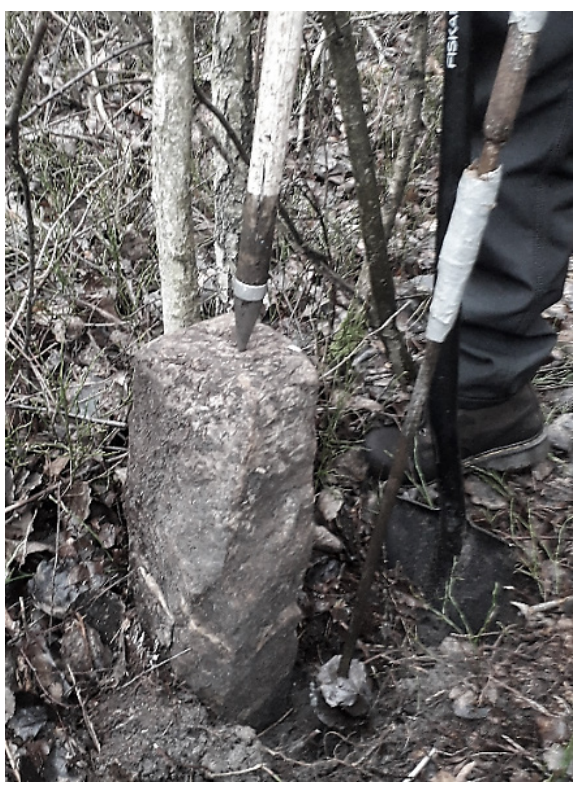

Fig. 5. Hand-made "ocios" $50 \mathrm{~cm}$ long 


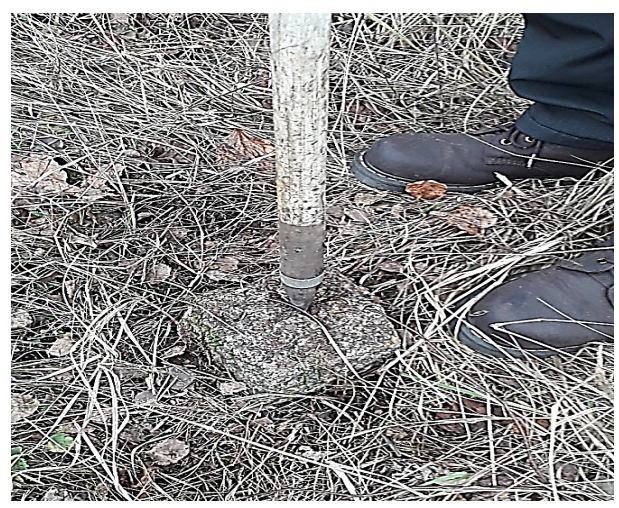

Fig. 6. Example of border coat with hand-made cross

In non-urbanized areas, another way of stabilizing the warp points was found at the border of forest private lands with state forest (pol. PGL Lasy Państwowe) land. The points were stabilized in boundary mounds with the use of granite signs (and not sand "ocios") with hand-made crosses (Fig. 7). The stabilization method in the form of conical boundary mounds was in accordance with the conditions specified in the instructions [11]. In the middle of the boundary mounds, however, no wooden piles were found - only granite signs. The stabilization of the polygon points in the form of granite signs was not in accordance with the technical instructions [11]. Moreover, such a stabilization method for the studied area was typical in a different time period. Granite signs have been used since the 1960s.

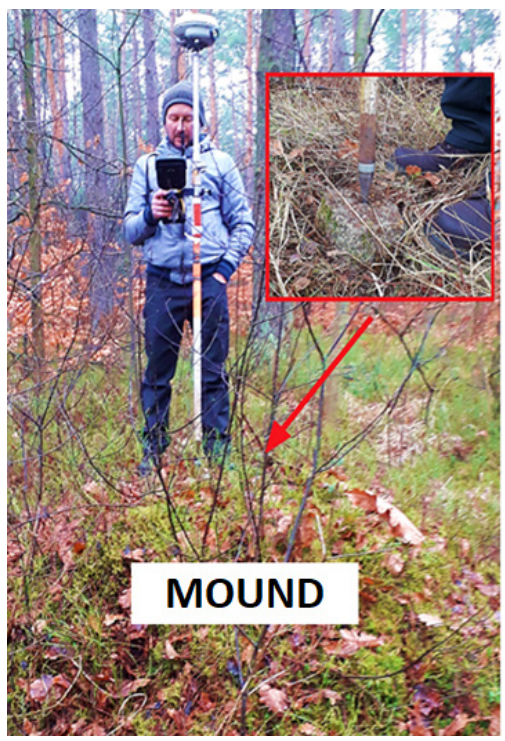

Fig. 7. Border mound with granite 


\subsection{Czarniecka Góra Unit}

In the area of the Czarniecka Góra unit, 6 of 53 network points used for consolidation were found and identified during the field work. During the measurement, the stabilization of the polygon points in the form of hand-made sand "ocios" with the shape of a truncated cone with a center diameter of about $2 \mathrm{~cm}$ found (Fig. 8).

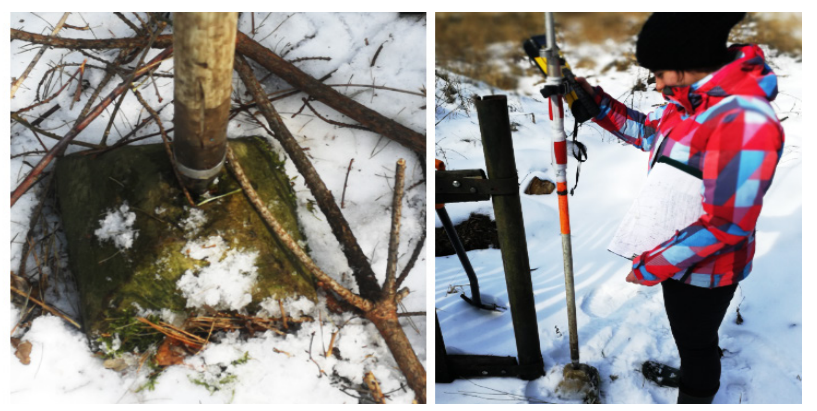

Fig. 8. Example of boundary wall with shape of truncated cone

Measurements of the field marks found in the field were carried out using the RTK method with a TRIMBLE R6 GPS receiver.

\section{Conducted Research}

Only the manuscript consolidation maps from the land consolidation documentation have been preserved in both of the analyzed cases in PZGiK. Coordinates of the network points used during the consolidation were not found. Therefore, on the basis of the list of measures (angles and lengths of the assumed polygon), the approximate coordinates of the network points were calculated in the local system. The network was then leveled using the least squares method. The average network point error after leveling was $0.25 \mathrm{~m}$ (Matyniów) and $0.14 \mathrm{~m}$ (Czarniecka Góra).

In the next stage of the work based on the found limit markings, a mathematical transformation of the coordinate points of the matrix using the Helmert method to the valid PUWP2000 system was made. This possibility is permitted by current technical standards [10]. A transformation error of $0.29 \mathrm{~m}$ (Matyniów) and $0.11 \mathrm{~m}$ (Czarniecka Góra) was obtained.

Transformations of the Matyniów unit network points were made based on 12 found points (Fig. 9). Due to the arrangement of the adaptation points for coordinate transformation, 12 of the 15 points found were used. The remaining three points were used as control points. In addition, due to the different method of stabilizing the points located at the border of the forest land, no granite signs were used for transformation because it was found that they did not come from the period of the analyzed consolidation (on the basis of the field work). 


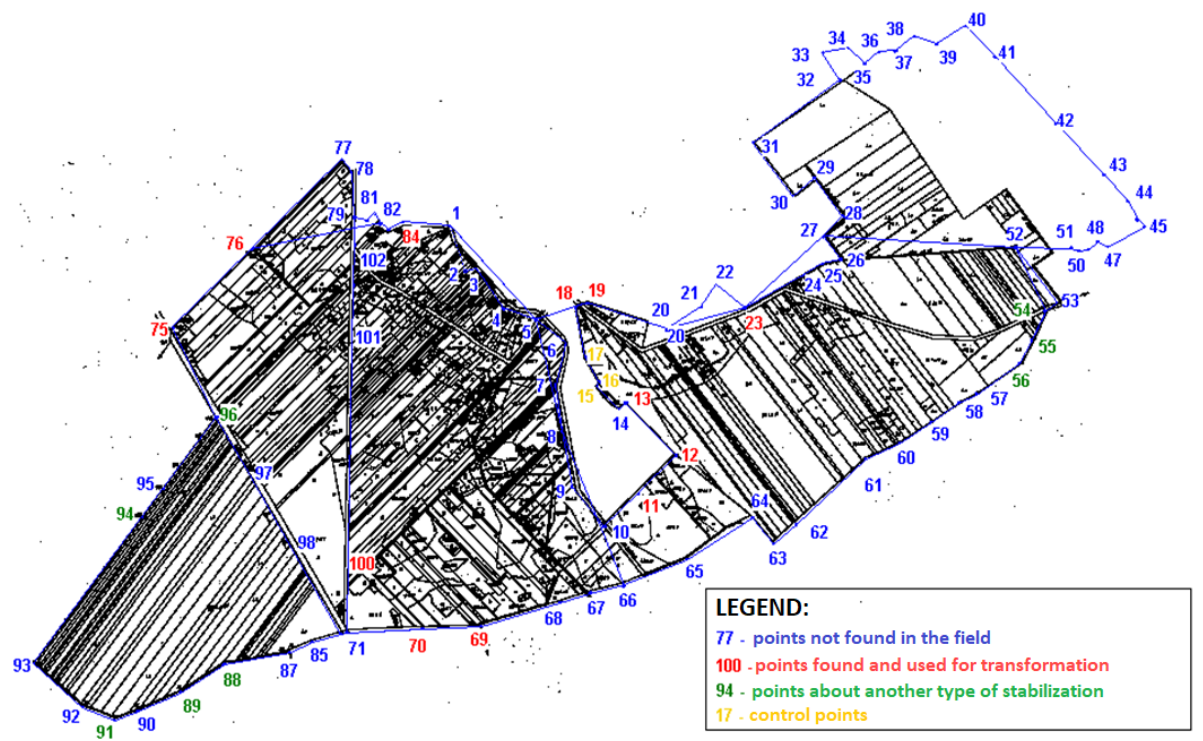

Fig. 9. Sketch of network with marking of used points - Matyniów

In the case of the Czarniecka Góra unit, the transformation was made on the basis of five points found, and one was used as a control point (Fig. 10).

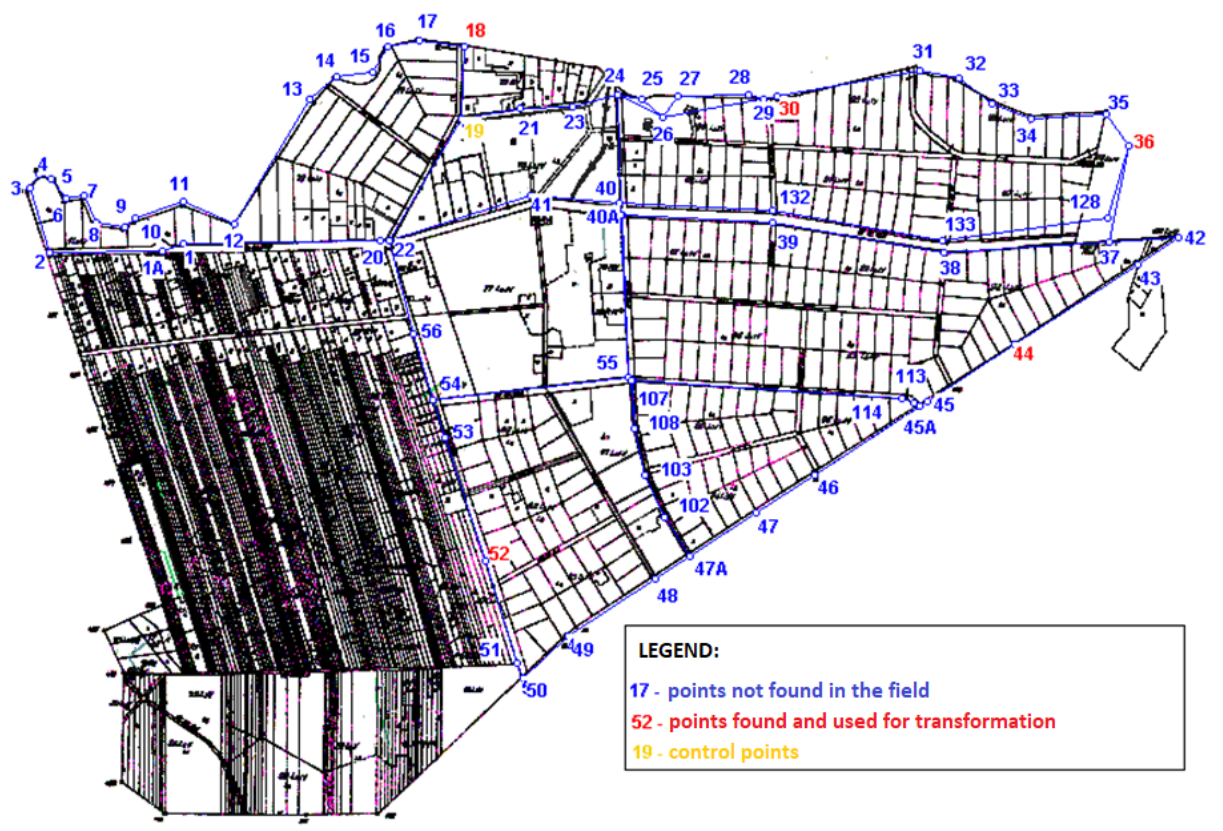

Fig. 10. Sketch of network with marking of used points - Czarniecka Góra 
Based on the average position error of the point after alignment and transformation error using Formula (1), the mean position error of the warp point was estimated. The results are shown in Table 1.

$$
m_{p}=\sqrt{m_{W}^{2}+m_{T}^{2}}
$$

where:

$m_{p}$ - estimated mean position error of network point,

$m_{W}$ - average error of point position after alignment,

$m_{T}$ - transformation error.

Table 1. Estimation of mean position error of network point

\begin{tabular}{|l|c|c|c|}
\hline \hline Analyzed unit & $m_{W}[\mathrm{~m}]$ & $m_{T}[\mathrm{~m}]$ & $m_{p}[\mathrm{~m}]$ \\
\hline \hline Matyniów & 0.25 & 0.29 & $\mathbf{0 . 3 8}$ \\
\hline Czarniecka Góra & 0.14 & 0.11 & $\mathbf{0 . 1 8}$ \\
\hline
\end{tabular}

In the next stage of work for control points and the found granite signs in which another stabilization method was found (Matyniów unit), the linear deviation value $\left(D_{p}\right)$ was calculated using the coordinates of the network points calculated on the basis of the transformation and the coordinates obtained from the measurement (Tab. 2). In red in Table 2, the points for which the values of the linear deviation exceed the values of the estimated mean position error of the point are marked.

Table 2. Value of linear deviation for selected points of network

\begin{tabular}{||c|c|c|c||}
\hline \hline Unit & Point number & $D_{p}[\mathrm{~m}]$ & Remarks \\
\hline \hline \multirow{5}{*}{ Matyniów } & 96 & 1.86 & granite \\
\cline { 2 - 4 } & 94 & 1.22 & granite \\
\cline { 2 - 4 } & 91 & 1.13 & granite \\
\cline { 2 - 4 } & 89 & 0.34 & granite \\
\cline { 2 - 4 } & 88 & 0.95 & granite \\
\cline { 2 - 4 } & 54 & 0.67 & granite \\
\cline { 2 - 4 } & 55 & 0.50 & granite \\
\cline { 2 - 5 } & 56 & 0.55 & granite \\
\cline { 2 - 5 } & 15 & 0.06 & control point \\
\cline { 2 - 5 } & 16 & 0.29 & control point \\
\cline { 2 - 5 } & 17 & 0.26 & control point \\
\hline Czarniecka Góra & 19 & 0.13 & \\
\hline
\end{tabular}


The calculations confirmed the conclusions made on the basis of field works carried out in the Matyniów unit that the granite signs were not stabilized during consolidation in the 1930s.

The linear deviation values for three selected control points within the Matyniów unit was less than the estimated error of the point location $-0.38 \mathrm{~m}$. Similar results were found in the area of Czarniecka Góra.

\section{Analysis of Usefulness}

According to Art. 39, Par. 1 of the Geodetic and Cartographic Law [7], the act of the resumption of border marks is subject to shifted, damaged, or destroyed marks that were previously established if there are documents allowing us to determine their original locations. However, as emphasized in $[5,8]$, the resumption of border marks should be carried out when the data disclosed in the resource allows us to determine the position of the characters with the accuracy required in applicable law. If this data does not meet the applicable standards, the boundaries should be determined in accordance with the Regulation on the Land and Building Register [8]. The currently required accuracy of determining the position of border points is $0.10 \mathrm{~m}$ in relation to the nearest points of the geodetic or measuring network [10] or $0.30 \mathrm{~m}$ in relation to the points of the Class I network [9].

In the analyzed cases, the consolidation of the villages of Matyniów and Czarniecka Góra in the District Center for Geodetic and Cartographic Documentation in the Końskie contain materials (a consolidation map) that allowed for the reconstruction of the original locations of the damaged border signs. The location of the boundary marks can be determined by calculations using the rectangular offset method based on the execution network assumed during integration.

According to the surveys carried out, the accuracy of the locations of the border marks determined on the basis of the land consolidation materials of the village of Matyniów will not meet the currently required criteria. For the area of Czarniecka Góra, the accuracy with which the original locations of the border marks can be reconstructed on the basis of the consolidation map is within acceptable limits.

In accordance with the applicable regulations and cited literature $[5,6,8]$ in the case of the Matyniów unit, the procedure for establishing the boundary should be applied in accordance with the Regulation on Land and Buildings Register in order to determine the course of the border in the area [9], while in the case of the land of the village of Czarniecka Góra, it would be appropriate to apply the procedure of the resumption of boundary marks in the mode of the Geodetic and Cartographic Law. 


\section{Conclusions}

On the basis of the conducted research, it was found that the pre-war Matyniów and Czarniecka Góra consolidation maps show a usefulness in the activities aimed at determining the borders in the fields. During the field work carried out, it was noticed that, field construction points have survived to this day, the despite stabilization 80 years ago.

Due to the fact that the accuracy of determining the initial locations of the boundary marks on the basis of the pre-war land consolidation of Matyniów does not currently meet the required accuracy - the appropriate procedure for defining the boundary will be the application of the procedure for establishing the boundary in the mode of the Regulation on Land and Buildings Register. In order to restore the original location of the border signs of the Czarniecka Góra unit, the procedure of the resumption of boundary marks in the mode of the Geodetic and Cartographic Law is allowed.

When selecting adaptation points for the purpose of determining the coordinates of the points of the execution network, it should be taken into account that the traces that are found do not always come from the consolidation period. In the analyzed case, despite the adoption of border mounds during the measurement work in the 1960s and 1970s, the original positions of the signs were changed, replacing wooden piles with granite signs. The use of granite signs as adaptation points during transformation would cause the incorrect determination of the coordinates of the network points, and as a result, the incorrect indication of the locations of the boundary signs in the field.

Based on the conducted analyses, it was found that the procedure to be applied when defining the boundaries based on pre-war consolidation maps cannot be clearly identified. The conducted research has shown that each case should be considered individually, because the accuracy with which the locations of border points can be determined today may differ from each other despite the similar time and manner of executing the consolidation proceedings in the past.

\section{References}

[1] Buśko M., Meusz A.: Current status of real estate cadastre in Poland with reference to historical conditions of different regions of the country Current status of real estate cadastre in Poland with reference to historical conditions of different regions of the country. [in:] Cygas D., Tollazzi T. (eds.), $9^{\text {th }}$ ICEE: The $9^{\text {th }}$ International Conference Environmental Engineering, May 22-23 2014, Vilnius, Lithuania: selected papers, Vilnius Gediminas Technical University Press, Vilnius, pp. 1-8 [electronic document].

[2] Li D., Shan J., Gong J. (eds.): Geospatial Technology for Earth Observation. Springer, Boston 2010. 
[3] Noga K., Gryboś F., Pałach M., Knoll Ł., Całka H., Radzio W., TomczykKrause I., Grabczyński R., Beściak P., Kukla A., Łyszczek D., Mączewski K., Brasse M., Pindelski J., Wojciechowski J., Kochański S., Dzinek D., Machnicka G., Niewadzisz G., Nieruchalska Z., Michalak M.: Polish cadastre yesterday, today and tomorrow. [in:] 2nd Cadastral Congress, Exhibition, Krakow (2003)

[4] Przewięźlikowska A., Skotnicki K.: Wykorzystanie pruskich i niemieckich oraz rosyjskich źródłowych materiałów katastralnych dla potrzeb współczesnych, wybranych prac geodezyjnych i zagadnień prawnych. Geodezja: półrocznik Akademii Górniczo-Hutniczej im. Stanisława Staszica w Krakowie, t. 7, z. 1, 2001, pp. 73-86.

[5] Mączyńska A.: Practical Problems of Implementing Selected Procedures Determining Course of Borders. Geomatics and Environmental Engineering, vol. 12, no. 1, 2018, pp. 77-90.

[6] Kwartnik Pruc A., Hanus P.. Geodezyjne aspekty rozgraniczeń i podziałów nieruchomości. Wydawnictwa AGH, Kraków 2014.

[7] Obwieszczenie Marszałka Sejmu Rzeczypospolitej Polskiej z dnia 12 września 2016 r. w sprawie ogłoszenia jednolitego tekstu ustawy - Prawo geodezyjne i kartograficzne. Dz.U. 2016, poz. 1629 [The Act of May 17, 1989. Geodetic and cartographic law. Journal of Laws 2016, item 1629, as amended].

[8] Wyrok WSA w Krakowie z 2015-01-30. III SA/Kr 1766/14 [Judgment of the Provincial Administrative Court in Krakow of 2015-01-30. III SA/Kr 1766/14], [on-line:] http://orzeczenia.nsa.gov.pl/doc/9367156B91.

[9] Obwieszczenie Ministra Infrastruktury i Budownictwa z dnia 10 czerwca 2016 r. w sprawie ogłoszenia jednolitego tekstu rozporzadzenia Ministra Rozwoju Regionalnego i Budownictwa w sprawie ewidencji gruntów i budynków. Dz.U. 2016, poz. 1034 [Regulation of the Minister of Regional Development and Construction regarding land registry and buildings of March 29, 2001. Journal of Laws 2016, item 1034, as amended].

[10] Rozporzadzenie Ministra Spraw Wewnętrznych i Administracji z dnia 9 listopada 2011 r. w sprawie standardów technicznych wykonywania geodezyjnych pomiarów sytuacyjnych i wysokościowych oraz opracowywania i przekazywania wyników tych pomiarów do państwowego zasobu geodezyjnego i kartograficznego. Dz.U. 2011, nr 263, poz. 1572 [Regulation of the Minister of the Interior and Administration of 9 November 2011. on technical standards for surveying situational measurements and heights and the elaboration and transmission of the results of these measurements to the state geodetic and cartographic resources. Journal of Laws 2011, No. 263, item 1572].

[11] Rozporządzenie Ministra Reform Rolnych z dnia 13 lutego 1925 r. o stosowaniu instrukcji technicznej do wykonywania prac pomiarowych, związanych z przebudową ustroju rolnego. Dz.U. 1925, nr 29, poz. 205 [Regulation of the Minister of Agricultural Reform of 13 February 1925 on the use of technical instructions for the performance of measurement work related to the reconstruction of the agricultural system. Journal of Laws 1925, No. 29, item 205, as amended]. 
[12] Obwieszczenie Ministra Reform Rolnych z dnia 29 września 1927 r. w sprawie ogłoszenia jednolitego tekstu ustawy z dnia 31 lipca 1923 roku o scalaniu gruntów. Dz.U. 1927, nr 92, poz. 833 [Act of July 31, 1923 on land consolidation. Journal of Laws 1927, No. 92, item 833, as amended].

[13] Ustawa z dnia 17 lutego 1932 r. w sprawie zmian w ustawie o zakresie działania Ministra Reform Rolnych i organizacji urzędów i komisyj ziemskich. Dz.U. 1932 nr 19 poz. 129 [Act of 17 February 1932 on amendments to the act on the scope of operation of the Minister of Agricultural Reform and organization of offices and commissions of the earth. Journal of Laws 1932, No. 19, item 129].

[14] Euczyński R.: Evolution of the accuracy criteria for the cadastral data base in Poland. [in:] GIS for Geoscientists, Nacionalna knjižnica, Zagreb 2012, pp. 107-119.

\section{Analiza przydatności przedwojennych map scaleniowych w wybranych procedurach określających przebieg granic na przykładzie obrębu Matyniów oraz Czarniecka Góra}

Streszczenie: Na terenach zaboru rosyjskiego odnajduje się materiały określające przebieg granic powstałe w okresie międzywojennym. Dokumentami taki są scalenia przedwojenne. Geodeci uprawnieni wykorzystuja podobne materiały w pracach mających na celu określenie przebiegu granicy w terenie. Na podstawie przedwojennych scaleń wykonawcy dokonują czynności wznowienia znaków granicznych zgodnie z art. 39 ustawy Prawo geodezyjne i kartograficzne lub czynności ustalenia przebiegu granic na podstawie 39 rozporządzenia w sprawie ewidencji gruntów i budynków.

W pracy przeanalizowano mapy scaleniowe gruntów wsi Matyniów oraz Czarniecka Góra położonych w powiecie koneckim województwa świętokrzyskiego w celu sprawdzenia, czy podobne materiały mogą stanowić podstawę do przeprowadzenia czynności wznowienia znaków granicznych.

\section{Słowa}

kluczowe: przedwojenne scalenia, wznowienie znaków granicznych, ewidencja gruntów 